\title{
CLINICAL OBSERVATION ON MALIGNANT EPIPHARYNX TUMORS IN OKINAWA PREFECTURE
}

\author{
NORIMASA MIYAKOGAWA, M. D. \\ Department of Otolaryngology, National Defense Medical College, Saitama \\ (Director: T. Inouye, M. D.)
}

Statistical observation of 226 cases of head and neck tumors, during the period of April, 1973, when Department of Ear, Nose and Throat was commenced, through March, 1978, was done at the Department of Otolaryngology, University Hospital of the Ryukyûs, College of Health Science, Okinawa.

The head and neck tumors were found in approximately 4,0\% of all the ENT patients in each year. The number of the patients and the locations of the malignant tumors were as follows: 38 cases $(16.8 \%)$ in the oral cavity, 76 cases $(33.6 \%)$ in the pharynx, 53 cases $(23.5 \%)$ in the larynx, 42 cases $(18.6 \%)$ in the nasal and paranasal cavities, 2 cases $(0.9 \%)$ in the acoustic organs and 15 cases $(6.6 \%)$ in the other head and neck region. The statistical details of malignant pharyngeal tumors were as follows:

1) Epipharyngeal tumors were found in 18 cases (23.7\%), oropharyngeal tumors in 38 cases $(50.0 \%)$ and laryngopharyngeal tumors in 20 cases $(26.3 \%)$ out of total 76 cases. Epipharyngeal tumors (18 cases) occupied $8.0 \%$ of the malignant head and neck tumors.

2) The ratio between males (14 cases) and females (4 cases) was 3.5 and 1.

3) The age was distributed from 20 to 66 years. Its incidence had two peaks. One was in the second decades and the other was in the fifth to sixth decades. The average age was 39.8 years, which was younger than that of other malignant tumors.

4) Nasal symptoms were noted in $36.8 \%$ of all initial symptoms of the malignant epipharyngeal tumors, aural symptoms in $23.7 \%$, cranial symptoms in $21.0 \%$, cervical symptoms in $15.8 \%$ and pharyngeal symptoms in $2.6 \%$. Cervical lymphadenopathy was found in $65.7 \%$ of the patients, unilaterally in 10 subjects $(83.3 \%)$ and bilaterally in 2 subjects (16.7\%).

5) Cranial nerve symptoms were noted in 3 cases.

6) The primary tumor sites were the posterior superior wall of the epiphrynx ( 10 cases, $55.6 \%$ ), lateral wall (7 cases, 38. $\% \%$ ), anterior wall ( 0 cases, $0 \%$ ) and unknown ( 1 cases, $6.6 \%)$.

7) Histopathologically, carcinomas were found in 19 cases ( $83.3 \%$ ), mostly squamous cell carcinoma, and sarcomas were found in 3 cases (16.7\%), mostly reticulum cell sarcoma.

8) According to TNM classification (UICC) and stage classification (The American Joint Committee), 3 cases (16.7\%) were in stage I, 2 cases (11.1\%) in stage II, 5 cases $(27.8 \%)$ in stage III, 7 cases (38.9\%) in stage IV and last one (5.6\%) was unknown. The advanced stages of III and IV were seen in 12 cases $(66.7 \%)$.

9) Most patients were treated by external radiation (mainly cobalt 60 irradiation), chemotherapy and immuno-chemotherapy.

10) The 3 year crude survival rate in 9 patients with malignant epipharyngeal tumors was approximately $44,4 \%$. 
11) Okinawa Prefecture is closely located to Formosa, where numerous cases of malignant epipharyngeal tumor are found. However, the incidence of malignant epipharyngeal tumors in Okinawa Prefecture was less than in Formosa.

\title{
A82-0656-51371 \\ 沖繩県にお忛る上咽頭悪性腫湟の臨床的観察
}

\author{
防衛医科大学校耳睤喵喉科学教室（主任：井上鉄三教授）
}

都川施正

\section{1. 緒言}

著者は既に昭和 48 年 4 月より昭和 52 年 3 月まで 4 年

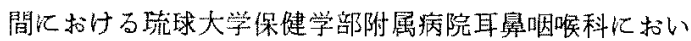

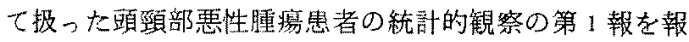
告した ${ }^{12}$. 今回は梳球大学保健学部附属病院耳鼻咽喉科 開設の昭和 48 年 4 月より昭和53年 3 月までの 5 年間に扱 った上咽頭悪性腫演例について臨床的観察を中心に捡討

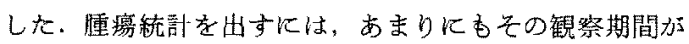
短加いが，沖䋥県に㧍ける実㷫を紹介することを目的と してここに報告することとした。

\section{2. 観 察 対 象}

昭和48年 4月より昭和53年3月ま゙の5年間に报った

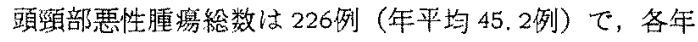
度共に患者総数の約 4\%を占めている.226例の内訳は， 备々口腔尰瘍 38例 (16.8\%)，咽頭腫富 76例 (33.6\%)，

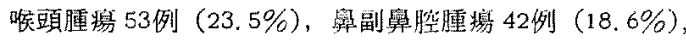
㯖器腫湟 2例 $(0.9 \%)$, その他 15例 $(6.6 \%)$ てあった。 76例の咽頭腫㿑は上咽頭腫瘍 18 例 (23.7\%), 中咽頭腫

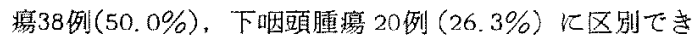

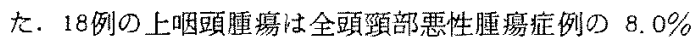
であった。また18例中17例は沖絙県出身の沖綶目民であ り1例は香港出身の中国人で本土の人は含ま机ていなか 斿.

\section{3. 年次的推移}

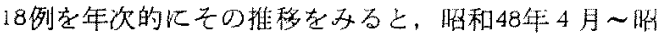
和 49 年 3 月 -4 例，昭和 49 年 4 月 昭和50年 3 月-2例, 昭和50年 4 月 昭和 51 年 3 月-6 例, 昭和 51 年 4 月 昭 和52年 3 月- 4 例，炤和 52 年 4 月 明和 53 年 3 月-2例, と多少の变動は認められたものの，流行を题わせるよう な者しい差はなか力た。

\section{4. 性・年龆分市}

表1亿示すように男性14例，女性4例で男女比は

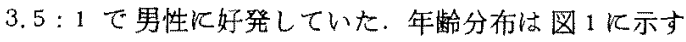
ように，20藏加ら66歳にかけて各年代に分布している が，20歳台と50〜60歳台に多発する傾向がみられた．最 年少は20歳男性, 最年長は66歳男性であり平均39.8歳で क力

表 1 Cancer of the Epipharynx (1)

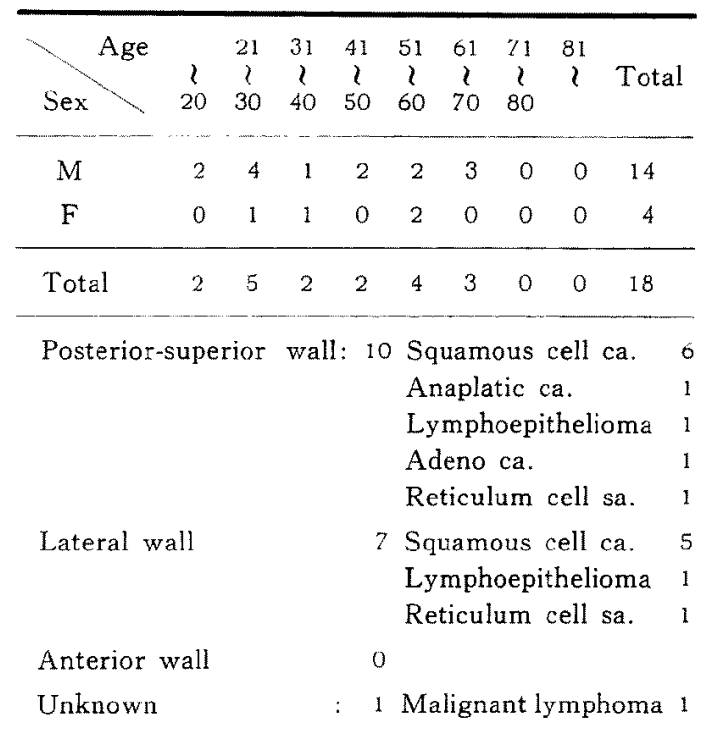

\section{5. 初発症状}

上咽頭は解剖学的に臨床的にも silent area と呼ば れるようにきわめて㟝断困難な部位であるから，初発症 状としては種々の掠状が举られている。すなわち舜症状 
表 2 Cancer of the Epipharynx (2)

Initial Symptoms

\begin{tabular}{|c|c|c|c|c|c|}
\hline \multirow{3}{*}{ Nasal symptoms } & (Nasal obstruction & $11)$ & & $28.9 \%$ & \multirow{3}{*}{$36.8 \%$} \\
\hline & Nasal bleeding & 2 & 14 & 5.3 & \\
\hline & Bloody discharge & 1) & & 2.6 & \\
\hline \multirow{3}{*}{ Aural symptoms } & (Tinnitis \& hearing loss & 6) & & 15.8 & \multirow{3}{*}{$23.7 \%$} \\
\hline & Otalgia & $1\}$ & 9 & 2.6 & \\
\hline & Fullness in the ear & 2) & & 5.3 & \\
\hline Cervical symptoms & Cervical lymphadenopathy & 6 & 6 & 15.8 & $15.8 \%$ \\
\hline \multirow[t]{2}{*}{ Pharyngeal symptoms } & Foreign body sensation & 1 & 1 & 2.6 & $2.6 \%$ \\
\hline & (Headache & 4) & \multirow{3}{*}{14} & 10.5 & \multirow{3}{*}{$21.0 \%$} \\
\hline \multirow[t]{2}{*}{ Cranial symptoms } & $\{$ Dysphagia & 3 & & 7.9 & \\
\hline & Abducens paralysis & 1) & & 2.6 & \\
\hline
\end{tabular}

が $36.8 \%$ で最も多く，ついで耳症状の $23.7 \%$, 脳神紾 症状の $21.0 \%$, 频部症状の $15.8 \%$, 咽頭症状の $2.6 \% の$ 順である，個々の症状別にみると，鼻閉11例(28.9\%)，

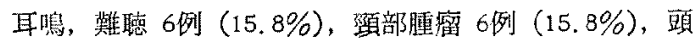
痛 4 例 $(10.0 \%)$ の順であった（㛄 2).

5. 坃移

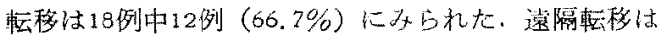
認められず，全例项部りン八節彰移で片側性のもの10例 (83.3\%), 雨側性のbのは2例 $(16.7 \%)$ であった.

\section{6. 脑神経症状}

初診時より脳神経症状を㒛ぬたものは，II，II， N， V，

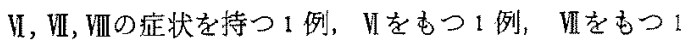
例で，比較的初診時より脳秆経障㶳を認めたものは少な 加った。

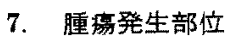

上咽頭を大さく，(1) 後上壁天蓋部，（2）側壁，(3)

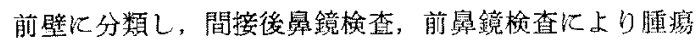
の発生部位を检討した（表 2)，乫れによると，後上壁 10 例 $(55.6 \%)$, 側壁 7 例 $(38.9 \%)$, 前壁0峢, 不明 1 例 (5.6\%) であった。

\section{8. 病理組織学的分類}

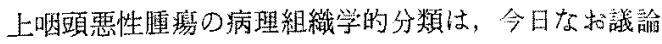
のタいところであり, 諸家の説が一致していないが, 耀 例を分類すると表 2 の通りである。しかし1967年のシン ガポールに怙ける䑁咽腔癌シンポジウムで，それまて lymphoepithelioma（リンパ上皮腫）と呼ばれてきたも の执よび，移行上皮癌はす心て扁平上皮癌とすべきであ ると決定されたので，その決定に徒うと，上皮性腄演と して扁平上皮癌13例 $(72,2 \%)$ ，腺癌1例，末分化癌1

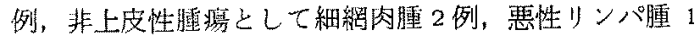
例であった。

\section{9. 睡惯迋展度および病期}

上咽頭の癌腫の進展度についての統一的な TNM分類 33)36)383993は UICC て决定されている.レントゲン撮影 在含め，解部紧的儿腫舅発生部位女後上壁，側壁，前壁 に分けて TNM を規定している。賣者はそれに徉って TNM 分類を行なった，それのみで㳙療効果，予後を 総合的飞判断することが困蜼なため, 病期分類 (stage classification）を本試みた，しかし今日な招一定の病期 分類が報告されていないため，著者は American Joint Committee の分類を参考にした。著者は初䧐時に分類

表 3 Cancer of the Epipharynx (3)

\begin{tabular}{|c|c|c|c|c|c|}
\hline Stage & Cases & Well & $\begin{array}{l}\text { Alive } \\
\text { with } \\
\text { Cancer }\end{array}$ & $\begin{array}{l}\text { Died } \\
\text { of } \\
\text { Cancer }\end{array}$ & Unkown \\
\hline I & 3 & 1 & 0 & 2 & 0 \\
\hline II & 2 & 0 & 0 & 2 & 0 \\
\hline III & 5 & 3 & 1 & 0 & 1 \\
\hline $\mathbb{N}$ & 7 & 2 & 0 & 5 & 0 \\
\hline Unknow & wn 1 & 0 & 0 & 1 & 0 \\
\hline Total & 18 & 6 & 1 & 10 & 1 \\
\hline \multicolumn{6}{|c|}{ Rad. } \\
\hline \multicolumn{6}{|c|}{ Rad. + Chem. '.................. 5} \\
\hline \multicolumn{6}{|c|}{ Rad. +Chem. + Imm. $\quad \cdots \cdots \cdots \cdot 7$} \\
\hline \multicolumn{6}{|c|}{ Rad. + Chem. + Ope. $\cdots \ldots \ldots \ldots \ldots$} \\
\hline & Chem. & & & …... I & \\
\hline
\end{tabular}


した結果を表 3に示したそそれれよると stage I一3例 $(16.7 \%)$, stage $\mathbb{I}-2$ 例 $(11.1 \%)$, stage $\mathbb{I}-5$ 例 $(27.8 \%)$, stage $\mathrm{N}-7$ 例 $(38.9 \%)$, 不明 -1 例 (5.6 \%). stage I， II 战合わせても $27.8 \%$ にすぎないが, stage III, IV を合和せると実に $66.7 \%$ となった。

\section{0. 治癔法およひ治瘄成稙}

上咽頭覀性腫第飞対する治療法としては，一般の悪

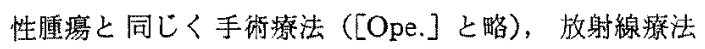
([放], Rad. と略)，化学療法（[化],Chem. と略）があ るが，最近では免疫化学療法 ([免]，Imm.上格) もこ れに加わっている。しかし上咽頭悪性腫演は前述のよう 飞進展例が多いこと, 病理組織学的彷放射線感受性の高 いものが多いことから手術燎法が選代れにくく，放射線 療法が逥ぼれることが压倒的である，著者恃コバルト照 射療法を中心として，化学療法括よび先疫化学潦法を併 用することとした。1例の手術例は 頭部廓清術である (表 3).

\section{1. 治療成縝}

全例の経過観察期間がまだ短かく遠隔成縝の3 年生存 率は 9 例中 4 例 $(44.4 \%)$ でる。全症例の現時点で

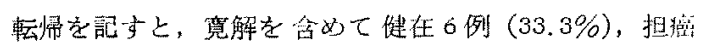
生存 1 例 $(5.6 \%)$, 䆆死 10 例 (55.6\%), 非癌死 0例, 不明 1 例 (5.6\%) である. stage II, NO12例中 6 例 (50.0\%) 㠰現在健在, 担癌生存の状態にある. 健在例 は（1）20歳(男) 扁平上皮癌 $\mathrm{T}_{1} \mathrm{~N}_{1} \mathrm{M}_{0}$ [放] + [化], （2）22埆(男）リンパ上皮腫 $\mathrm{T}_{2} \mathrm{~N}_{1} \mathrm{M}_{0}$ [放 $]+[$ 化],

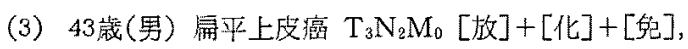

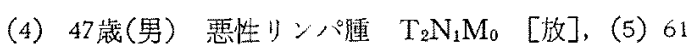
歳(男) 扁平上皮癌 $\mathrm{T}_{2} \mathrm{~N}_{2} \mathrm{M}_{0}$ [放 $]+[$ 化 $]+[$ 兔 $]$ ，担 癌生存の 1 例は 55 歳(男) 埛平上皮㾔 $\mathrm{T}_{2} \mathrm{~N}_{1} \mathrm{M}_{0}$ [坆] $+[$ 化 $]+[$ 免 $]$ である。

\section{考 察}

上咽頭悪性腫場は欧米人には稀て，東洋人ことに中国 人に压倒的に多いということは過去のいくつかの文献に

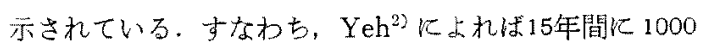
例，年平均66.7例だったと報告して朽り，Digby ${ }^{32}$ の報

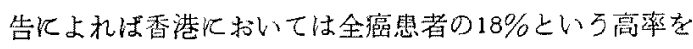
示している. Martin とQuan'は，特江日本人をのぞ く東洋人に民族特異性が認められる上報告した。Vaeth 5) は2. $4 \%$, Wang ${ }^{6)}$ は $0.5 \sim 2.5 \%$, Godtfredsen ${ }^{3) 8)}$

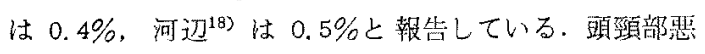
性腫瘍中の本疾患の占める割合飞ついて，Martin ${ }^{92}$ は 2 \%であるとし，在米中国人で米国で生机者の中に性
疾患は 1 例もな加ったとしている。

$\mathrm{RaO}^{10)}$ は $1.4 \%$, Simmons ${ }^{11}$ は $0.7 \%$, Godtfredsen 2)83 は0. $8 \%$, Pang ${ }^{123}$ は出生地にかかわらず在米中国人

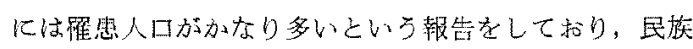

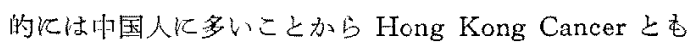

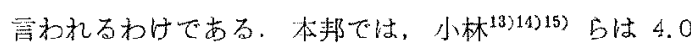

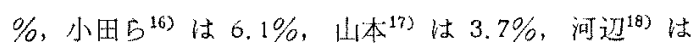
$4.8 \%$ ，竹田 $5^{192}$ 汇 $11.5 \%$, 馬場 $5^{20)}$ は $6.3 \%$ ，佐藤 ら 21 沬 $5.8 \%$ と報告している。著者のデータては 226

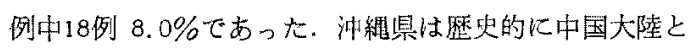
関係が梁く，他方地理的飞台湾飞近接しているとこうか 占高率の発生が予想さ机た。沢木 ${ }^{37}$ はその奏態は日本 本上と同様汇低率を示したと述べているが著者の $8.0 \%$

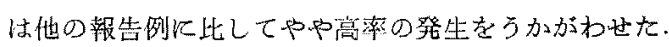

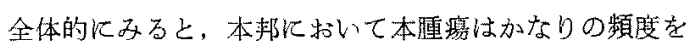
占め決して稀な疾恵上はいえないと考党る。

性别発生頻度に関しては，ずて男性に好発している 報告が多い，欧米で忙 Lederman ${ }^{2223)}$, Godtfredsen ${ }^{7882}$, Hara $^{24)}$ (更女比 2:1, Bloom ${ }^{25)}$, Pang ${ }^{12)}$, Perez ${ }^{267}$ Б は3:1 と辩告している、本邦ては河边 ${ }^{18)}$ は $3.6: 1$,小

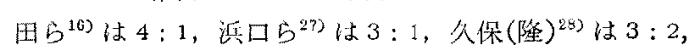

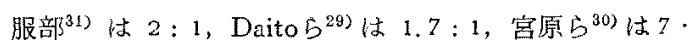
3 と報告し，著者の症例では $3.5: 1$ で諸家の報告と同 じ傾向であった。

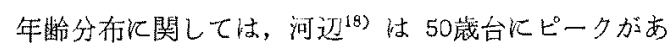
ったといい，服部311 は60藏台にピークが支ったという。 宮原 ${ }^{3(3)}$ は 40 60藏台炕 67\%を占め年榆首がやや若か ったと述べている，一方，三吉32）は，20藏台と60歳台 に2つのピークを認めている。渚者の症例では，20〜60 歳台にかけて各年秢風飞分布しているが，20歳台と60藏

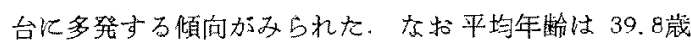
であり諸家の報告より少し若い傾向が認められた。

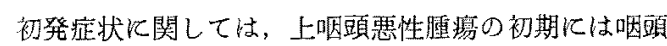
自体の特有の局所症状を示さないので, 腫演の原病楽が

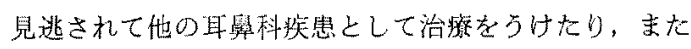

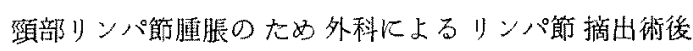

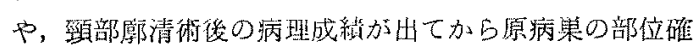
定のため耳舅科任化頼され，上咽頭腫瘳を発見するな

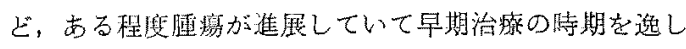
ている症例の多いことは諸家に上り指摘されている。す

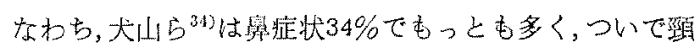
部症状 $31 \%$ ，正症状 $19 \%$ の順であり，個々の症状別儿

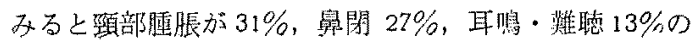




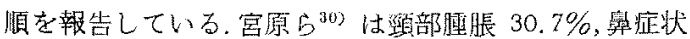
$29.1 \%$, 耳症状 $22.6 \%$, 脳神経聇状 $15.6 \%$, 珚頭腚状

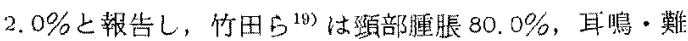

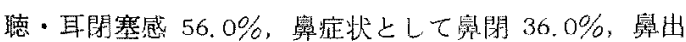
血 $23.7 \%$ ，脳神経症状 $21.0 \%$ ，新部腫脤 $15.8 \%$ ，咽頭 症状 $2.6 \%$ と報告している. Wang $\dot{5}^{6)}$, Lederman ${ }^{2232:)}$,

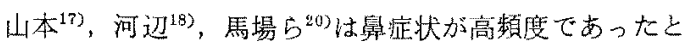
報告して却り，犬山 $5^{34)}$, 宮原 $5^{30)}$, 竹田 ${ }^{14)}$, Molony ${ }^{35)}$ は頸部症状が最も多いと层告している。

頸部リンパ節転移の頻度については，Lederman ${ }^{22239}$ $70 \%$, Wang $5^{6)} 63.5 \%$, 山我 ${ }^{17} 66.7 \%$, 河辽 ${ }^{18} 81.0$ $\%$ ，竹由 $5^{19} 92 \% ，$ 馬埸 $b^{20)} 75.0 \%$ ，著者のそ水は $66.7 \%$ 上大体 $70 \%$ 前後の報告が多い，一側の枟移は，

Wang $5^{6)}$ ，山本 ${ }^{17}$. 河边 ${ }^{15\rangle}$ Kよると $33 \sim 52 \%$ である が，著者例では 83.3\%とかなり高率であった。

腫鸄の発生部位は，前述のことく左右上咽頭側壁，上 咽頭天蓄部扣よび前壁に分けられる。上咽頭側壁行好発 する報告は，Lederman ${ }^{2223)} 33.6 \% ， \operatorname{Rao}^{103} 43.7 \%$ ， 河辺 ${ }^{182} 52.7 \%$, 服部 ${ }^{312} 53.9 \%$ ，山本 ${ }^{17)} 57 \%$ ，小林与 ${ }^{13314) 153} 37.0 \%$ ，久保(隆) $5^{283} 43 \%$ ，宮原 $5^{303} 56.3 \%$

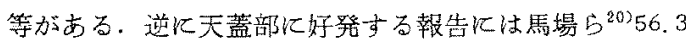

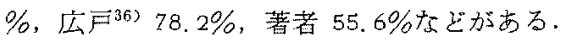

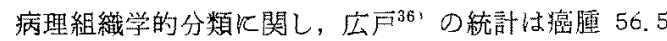

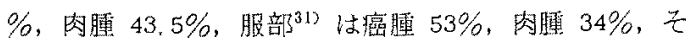
の他 $13 \%$ としている，著者例では $83 \%$ が癌腫であった。

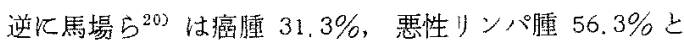
肉腫の多い報皆皇出ている。

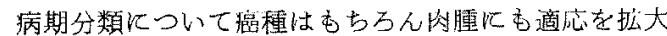
して UICC の TNM分類 ${ }^{33398393}$ をあてはよ， stage は American Joint Committee の份類を参考比した. 河 辺 $^{19)}$ 仗 $\mathrm{I} \sim \mathrm{V}$ 型江分類し $\mathrm{I}$ 型 $\left(\mathrm{T}_{1}\right)-11.1 \%$. II 型 $\left(\mathrm{T}_{2}\right)$ $-33.3 \%$ ，正型 $\left(T_{3}\right)-11.1 \%, N$ 型 $\left(T_{4}\right)-44.4 \%$ であり,

相型，W型を合わせて 55.5\%でありかなりの進展走

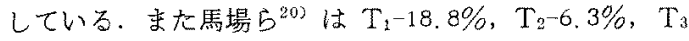
$-31.4 \%, \mathrm{~T}_{A}-43.8 \%$ ありり $\mathrm{T}_{3}$ と $\mathrm{T}_{4}$ とで害に $75.2 \%$ であったと報告している、著者例では前記分類にて stage I-16.7\%, stage II $-11.1 \%$, stage III $-27.8 \%$, stage

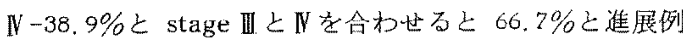
加多加った。

本疾㭧の治療法については放射線感受性の高い腄痬が 多く，解剖学的位置加与考无放射線湶法加主流古占力て いる，手術療法，化学療法就よび免疫瘵法についても各 種の報告がなされているが，著者は原則として照射噔法

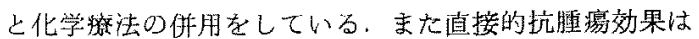

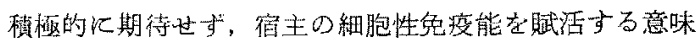

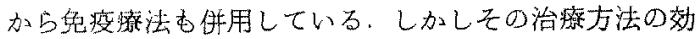
鼠判定と成續は症例数が少なく，観察期間がまだあまり に毛短加が，3年生存率は $44.4 \%$ であった。今回は 現時点ての檕就の孙とて和く。

\section{ま $め$}

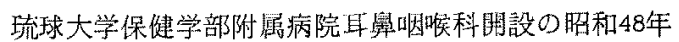
4 月より昭和 53 年 3 月までの5 年間に报った頭頸部悪性

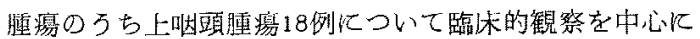

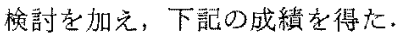

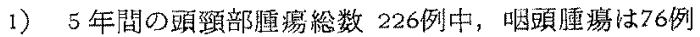
(33.6\%) ですり，上咽頭腫煬は18例 (8.0\%)であっ t.

2) 本唉慧18例中，男性14例，女性 4 例で男女比は 3.5

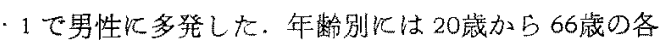

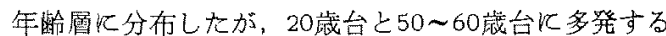
傾向がタられた。

3）初発症状峙䫶症状 $36.8 \%$, 耳症状 $23.7 \%$, 脸神経 症状 $21.0 \%$, 所部症状 $15.8 \%$, 咽頙症状 $2.6 \%$ 順

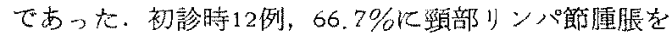
認めた。

4）初診時より絪神経症状を示したものは3例であっ た.

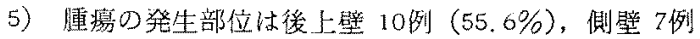
(38.9\%), 前壁 O例, 不明 1 例(5.6\%) でった。

6) 病理組織学的分類では癌腫 15 例 $(83.3 \%)$, 肉腫 3 例 $(16.7 \%)$ であった。

7) 揰疼進展度扎よび病期では, stage 1-3例(16.7\%), stage II-2例 $(11.1 \%)$, stage II-5例 $(27.8 \%)$, stage $N-7$ 例 $(38.9 \%)$, 不明 -1 例 (5.6\%) で,

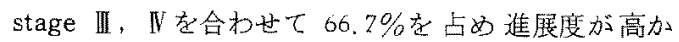
比.

8）治療方法はコバルト照射療法を中心化学源法, 免 疫療法を併用した。

9）治療成績を出す红早邀ぎるが，9例の3年生存率 は 44.4\%であり, 全例の現時点での転帰汁健在一6例 $(33.3 \%)$, 担崲生存- 1 例 $(5,6 \%)$, 癌死-10例 (55.6 $\%)$, 非癌死一0例, 不明-1例 $(5.6 \%)$ であった。

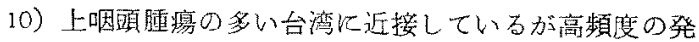
症はないが、本忙机ける他家の報告化比してやや高 加大。 


\section{参考 文 献}

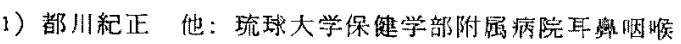

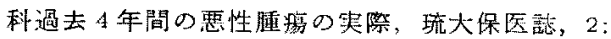
158-166, 1978.

2) $Y e h S:$ A histological classification of carcinoma of the nasopharynx with a critical review as to the existence of lymphoepitheliomas, Cancer, 15 : 895-920, 1962.

3) Digby $K H$, et al.: Nasopharyngeal malignancy, Brit. J. Surg., 28: 517-537, 1941.

4) Martin $H$ and Quan $S$ : The radical incidence (chinese) of nasopharyngeal cancer, Ann. Otol., Rhin. \& Laryng., 60: 168-173, 1951.

5) Vaeth $J M$ : Nasopharyngeal malignant tumors: 82 consecutive patients treated in a period of twenty-two years, Radiology, 74:364-372, 1960.

6) Wang $C C$, et al.: Cancer of the nasopharynx; its clinical and therapeutic considerations, Cancer, 15: 921-926, 1962.

7) Godtfredsen E: Ophthamologic and neurogic symptoms of malignant tumors of the nasopharyngeal wall, Acta phychiant, et neurol., supp. 34: 1-323, 1944.

8) Godtfredsen E: Diagnostic and prognostic roles of ophthalmoneurogic signs and symptoms in malignant nasopharyngeal tumors, Amer. Jour. Ophthal., 59: 1063-1069, 1965.

9) Martin $H$ : Cervical lymphnode metastasis as the first symptom of cancer, Surg. Gyn. \& Obst., 78: $133-159,1944$.

10) Rao $P B$ : Malignant tumors of nasopharynx in Dehli, J. Laryng. Otol., 80: 151-158, 1966.

11) Simmons $M W$ and Ariel $I M$ : Carcinoma of the nasopharynx, Surg. Gyn. \& Obst., 88: 763775,1949 .

12) Pang $L Q$ : Carcinoma of the nasopharynx, Ann. Otol., Rhin. \& Laryng., 68: 356-37 1, 1959.

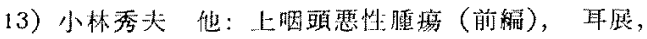
$7: 10 \cdots 13,1964$.

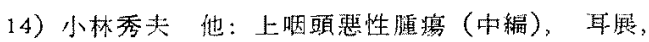
8: $19-24,1965$

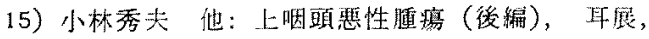
8: $128-133,1965$.

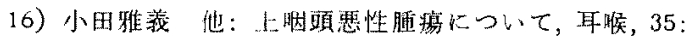
$65-68,1963$.

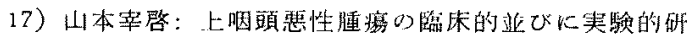

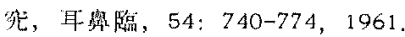

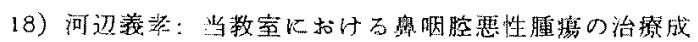
緗について，耳與臨，57：530-538，1964,

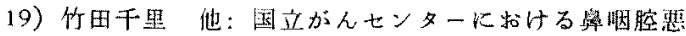

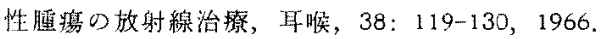

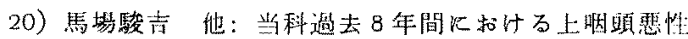

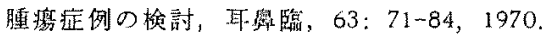

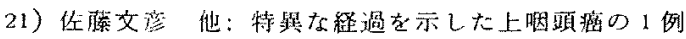

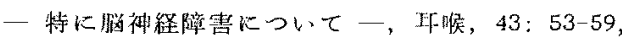
1971.

22) Lederman $M$; Cancer of the nasopharynx. its natural history and treatment, Springfield, III, 1961 .

23) Lederman $M$ : Cancer of the pharynx, J. Laryng. Otol., 81: 151-172, 1967.

24) Hara $H J$ : Review of 41 malignant tumors of the nasopharynx, Ann. Otol., 74., 74: 84-93, 1965.

25) Bloom $S M$ : Cancer of the nasopharynx, Laryngoscope, 71: 1207-1260, 1961

26) Perez $C A$, et al.: Cancer of the nasopharynx. Factors influencing prognosis, Cancer, 24: 1-17, 1969.

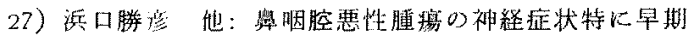
讋断の立場加与，最新医学，22：1788-1795，1967.

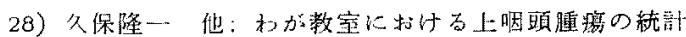

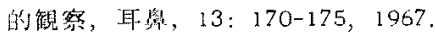

29) Daito $T$, et al.: Neoplasma of the nasopharynx, (review of 68 cases which appeared in Japanese literature), Arch. Otolaryng., 56: 45-48, 1952.

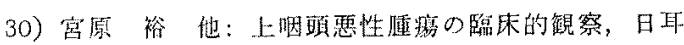
畄, 75: 355-371, 1972.

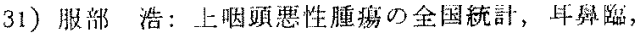
59: $581-584,1966$

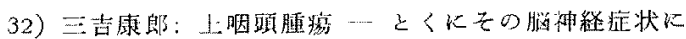

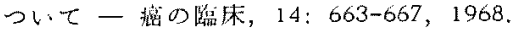

33) TNM classification of malignant tumors, UICC. Geneva, 1974.

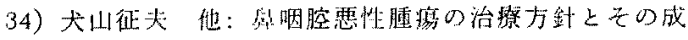

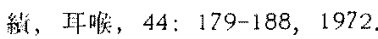

$7-21$ 
35) Molony $Y J$ : Malignant tumors of the nasopharynx, Laryngoscope, 67: 1297-1305, 1957.

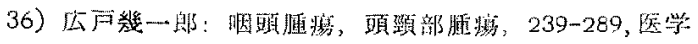
留院，1971。

37）沢木修二：上㸶磌癌，其喉，50：95-107，1978.

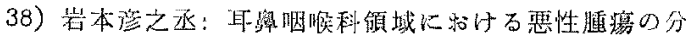

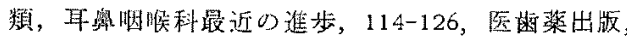
1968.

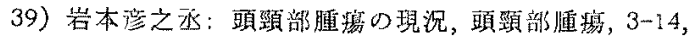
医学雷院, 1971.

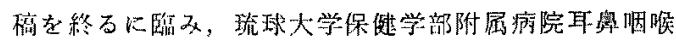

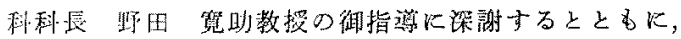

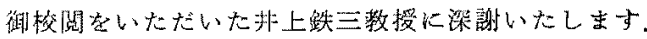

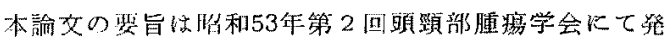
战した。

（原稿受优 昭和54，3．5日）

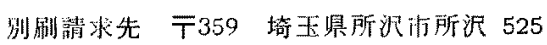

防符医科大学校耳器唄喉科学教室 都川 紀正 